\title{
Editorial
}

\section{Reflections on Literature and Art at a Time of Pandemic}

\author{
Tirtha Prasad Mukhopadhyay \\ Profesor Titular, Miembro de Sistema Nacional de Investigadores (Nivel I), CONACyT, \\ Mexico, Departamento de Arte y Empresa, Universidad de Guanajuato, Mexico. Chief \\ Editor, Rupkatha Journal on Interdisciplinary Studies in Humanities. \\ Email: chiefeditor@rupkatha.com
}

Imagine the dystopia created by this viral holocaust. Incendiary piers start, burning bodies in wastelands. At night wastelands reportedly turn into a mass crematorium. At a University hospital in New Jersey, the bell rings every half an hour, announcing the passing away of a Covid victim. Ideas of nation states, frontiers, countries have only enclosed people in prisons of illusion.

Such unreal lineations become fault lines for nationalism, migrations, war and hierarchical exclusion. The Corona virus however is not impeded by such boundaries. It transmits from human to human; it affects people without distinction of nationality, economics, franchise, and turns humans into targets with a kind of Dawkinsian indifference.

On the other hand, though, the virus innervates solidarity in humans, which is manifest as the indivisibility of the herd. Yet, we are only capable of ignorant and conflicted response towards the possible evolution of, what Petrashov called, 'noocenosic' ecosystems. For Petrashov, biological agents like humans would have to compromise to co-exist or live with other powerful collectives like the virus and similar nanometrical entities that percolate through this wide world. On several occasions we may not have adequate knowledge about coping with threats that are so microscopic and intangible. Various respond activities have been proposed. Contrasted to proposals of precautionary survival aided by statistical indicators, we hear of views like that of some Swedish administrators who say that forced quarantine strategies are already conditioned by biopolitical responses to acts of war and terrorism. Epidemiological caution is supposedly built on a politics of panoptical surveillance. Hence it is not an indispensable tool in the management of the pandemic. Social evolutionary thinkers like Stephen Goundry speaks of the physically interactive gestures tht are necessary for social life and survival, and say that quarantining goes against natural human evolution.

2.

But the virus has forced us to reconsider what it means to live under the fear of death or even speciate extinction. This is where the artist's personality comes at stake - since the artist, like all other human beings, is just another human being who has to respond to signals in its immediate environment, sometimes erroneously drifting, and sometimes doing the right thing. The virus has also generally coerced us to recognize true human worth out of the consciousness of our fragile life in the biological world. This global pandemic gives us a moment to reflect on the nervous and weedy layers of artifice that we have used to cover life's raw and beautiful texture. The virus has instigated a psychosis in terms of not just statistical effects of disease and precipitant mental depression but from its threats to creative life. Biological virulence, is linked to media virulence, it

(C) AesthetixMS 2020. This Open Access article is published under a Creative Commons Attribution Non-Commercial 4.o International License (http://creativecommons.org/licenses/by-nc/4.o/), which permits non-commercial re-use, distribution, and reproduction in any medium, provided the original work is properly cited. For citation use the DOI. For commercial re-use, please contact editor@rupkatha.com. 
turns human creativity into a whimpering shot in the dark. On a daily basis, we seem to be trapped in a world constantly manipulated by media pseudologies. There is little scope of independent thinking. Good examples of independent thinking are not hard to find though. Pepe Mujica, the former president of Uruguay, who was called "the poorest President" by the BBC, has a wonderful precept from Montevideo, where he tried to experiment with a lifestyle statement that was aimed at a distant and long-term amelioration of narcotic traffic in Central America. Mujica's lessons were easy and difficult to achieve at the same time - he demonstrated that narcotic economy results from human greed of material things, not for substance abusers, which is another problem elsewhere, but for poor people in Uruguay, El Salvador, Colombia and other countries, who participated in the trade. Mujica's own life, like Gandhi's, was a demonstrable proof of this grand simplicity that touches the core of our humanity.

In a world where 'art' has become a product of investment economy, it is now time to acknowledge that anonymous art is better than art of the genius. Folk art is superior to masterpieces. Ritual is superior to art in a show-case. True novels are lived rather than parcelled out by the giant media. Neatness is more beautiful than décor and an unassuming home is more divinely aesthetic than a furnished salon with books printed by the media houses.

The project hence is to liberate humane expression from cinders of decadent royalty and big business, and from the fantasies spotlighted by newspapers and TV news. The virus forces us to confide in the warmth and love of home. It is the same love that preserves us at any time of want or hardship. Anthropophilia causes us to care for each other. It makes us committed and risk our life for others. It is this capacity to empathise that saves us. Empathy, care, regard for others and for kin, are more important than any art that the media celebrates. The human being sacrifices love in order to become a monster of one's passion - but no good comes out of it. The friendship of working class people is more precious than the social prestige commanded by the elite. The painted face of the news presenter secretly mocks at the ineptitude of the common man.

\section{3.}

The virus cannot be taken as an incentive to create "viral poetry", as a testament of human art, like an Instagram post without any meaning beyond the instant. Browsing through the poetry section of last week's Vanity Fair, we see on its page, the same incongruous union of contemporary "vanity" and "art". The very title is pompous and instantaneous: "Why Poetry Is Having a Moment Amid the Global Quarantine". As we read further we are introduced to the post-marketing world: "The poem is enjoying a bump in cultural relevance as the world sits at home and considers its surroundings. Why your timeline is possibly suddenly sprinkled with verse". The Vanity Fair article is a precise reminder of how the same interweaving wealth of media magnate, collector, consumer and wealthy business personnel, fashion industry, 'art' is also actively spreading an idea of its own self-organizing poetry or art. The obnoxious twitter, the rigmarole of all things flashy and apple, blend wirh the empty tragedy of people locked at home.

The University in America, and many countries of Europe, has become a votary of the same class culture that prepares you for this world of quick sensations. In such times as now, we are compelled to ask "How does a novel apprised in New York impact the life of a villager in East Africa, or a lemon picker in Michoacan, or the trash collector in Kolkata's marshlands. The media novelist, so gorgeously fetishized in the academy, is no more than a colonial and pseudoprogessive metrosexual. Museums worldwide have become abominable machines of the destruction of human spirit. The Metropoitan Museum of Modern Art once exhibited works of an indigenous artist. After the exhibition, the artist asked for a little compensation for transport and 
installation of the exhibits. The museum said, that they displayed his work was a lot of investmet in itself - and that he should be grateful for that. The MOMA arrogance exposes the real values of the art world. Consider the invisible way in which a critic in The New Yorker creates these neocolonial evaluations for a piece of painting. She says on the home page, "Museums know the desires of our hands. The special presence of paintings comes from their being at once untouchable and viscerally evocative of touch. (April 21, 2020)”. A piece of painting is never so important, that it will continue to invoke our presence for its self-fetishization. Painting does not transcend life and humanity - it does not need to sit in a museum and make its own publicity look so arrogant and inhumane, waiting for its bidder, and its entry into the house of a collector.

4 .

True human values lie in the honesty of the heart, even of it is not 'artistic' by the world's standards. There may be true worth in the greatest of writings, but its appropriation by the industrial elite, has overshadowed its preciousness in a world of self-mesmerizing profanities. Creative writing should be undertaken in one's own language, criticism should enrich one's own culture and values. The unthinking study and glorification of Anglophone discourse, out of which we can scarcely escape, automatically aligns us to the media elite that tries to control the world's markets. As long as we don't shift our attention from the sufferings of our fellow humans we shall not render a disservice to people who speak the same language as ours, who reap the fruits, flowers and grain that sustain us. True beauty is tied to this simple life of communications. The viral moment has now created a space of introspection. It lets us focus on the essential spark of life. Academic discussions have been alienating us for long time. The best definition of creative process is to be creative, explore - each one, one's true hope and dream. and to hope for expiation through a humble word. It would be time, in a world freed from the virus, to identify and negate the presence of all brands of elitism. 